\title{
PENERAPAN METODE INSIDE OUTSIDE CIRCLE UNTUK MENINGKATKAN HASIL BELAJAR IPA PADA SISWA KELAS III SD NEGERI 2 KAWALU
}

\author{
Haryati \\ SD Negeri 2 Kawalu, Jl. Air Tanjung No.43, Kawalu, Tasikmalaya, Indonesia \\ Email: haryatiii1201@gmail.com
}

\begin{abstract}
This study aims to find out the use of Inside Outside Cirle method to improve Science learning outcomes in grade III SD Negeri 2 Kawalu Kota Tasikmalaya. The research involving the 25 students is conducted from August to September 2019 (2 months). This Classroom Action Research consists of 2 cycles, each of which consists of 4 stages, namely, planning, implementing, observing, and reflecting. Data collection methods used are written tests, observation sheets, and documentation. The data are analysed by comparing the value of the KKM achievement which was marked by an increase in Classical Completeness Criteria of each cycle. Based on the results of research in cycles I and II, with KKM of Science subjects is 70, the following data were obtained: 1) before using the Inside Outside Circle method, there are only 9 (36\%) students are complete, while 16 (64\%) students do not reach the KKM with the new average value covers 58.16; 2)After the Inside Outside Circle method is applied in Science subjects in the first cycle, the average value of student learning is 68.52 with 15 (60\%) students are complete, and 10 (40\%) students are not complete; 3)After reflection in cycle II, there is an increase in learning outcomes with an average score increasing to 80.28, and 20 (80\%) students who are complete, while $5(20 \%)$ students are not complete or do not meet the specified KKM. It can be concluded by using the Inside Outside Circle method, the learning outcomes of grade III students at SD Negeri 2 Kawalu Kota Tasikmalaya increased.
\end{abstract}

Keywords: Learning Outcomes, Inside Outside Circle Method

\begin{abstract}
ABSTRAK
Penelitian ini bertujuan untuk mengetahui penggunaan metode Inside Outside Circle untuk meningkatkan hasil belajar IPA pada siswa kelas III SD Negeri 2 Kawalu Kota Tasikmalaya. Subjek penelitian terdiri dari 25 siswa. Penelitian dilakukan selama 2 bulan mulai bulan Agustus sampai dengan September 2019. Penelitian Tindakan Kelas ini terdiri dari 2 siklus, masing-masing siklus terdiri dari 4 tahap yaitu perencanaan, pelaksanaan, observasi dan refleksi. Metode pengumpulan data yang digunakan adalah tes tertulis, lembar observasi, dan dokumentasi. Data dianalisa dengan membandingkan nilai pencapaian KKM yang ditandai dengan adanya peningkatan Kriteria Ketuntasan Klasikal pada setiap siklusnya. Berdasarkan hasil penelitian pada siklus I dan II, dengan KKM pada mata pelajaran IPA adalah 70, diperoleh data sebagai berikut:1) sebelum menggunakan metode Inside Outside Circle hanya ada 9 (36\%) siswa yang tuntas, sedangkan 16 (64\%) siswa belum mencapai KKM dengan rata-rata nilai baru mencapai 58,16; 2)Setelah diterapkan metode Inside Outside Circle dalam mata pelajaran IPA pada siklus I, nilai rata-rata belajar siswa sebesar 68,52 dengan $15(60 \%)$ siswa tuntas, dan $10(40 \%)$ siswa tidak tuntas; 3) Setelah dilakukan refleksi pada siklus II, terjadi peningkatan hasil belajar dengan nilai rata-rata meningkat menjadi sebesar 80,28 dan siswa yang tuntas sebanyak $20(80 \%)$, sedangkan $5(20 \%)$ orang siswa tidak tuntas atau belum memenuhi KKM yang ditentukan. Hasil penelitian dapat disimpulkan bahwa dengan menggunakan metode Inside Outside Circle, hasil belajar siswa kelas III SD Negeri 2 Kawalu Kota Tasikmalaya meningkat.
\end{abstract}

Kata Kunci : Hasil Belajar, Metode Inside Outside Circle

Cara sitasi: Haryati. (2020). Penerapan Metode Inside Outside Circle untuk Meningkatkan Hasil Belajar IPA pada Siswa Kelas III SD Negeri 2 Kawalu. J-KIP (Jurnal Keguruan dan IImu Pendidikan), 1 (2), 71-78. 


\section{PENDAHULUAN}

Mutu pendidikan di tingkat Sekolah Dasar masih jauh dari yang kita harapkan. Para peserta didik masih menggantungkan sepenuhnya hasil belajarnya pada materi pelajaran yang diberikan oleh guru. Mereka kurang kreatif dan terkesan tidak mau mempelajari hal-hal lain di luar hal yang diajarkan oleh guru. Di dalam kelas masih banyak terjadi komunikasi satu arah. Guru yang aktif mengajar dan siswa hanya mendengarkan apa yang diajarkan guru baru kemudian melakukan apa-apa sesuai perintah guru. Hal inilah yang sering menyebabkan prestasi belajar siswa kurang memuaskan. Selain itu, jumlah siswa dalam satu kelas yang terlalu banyak menjadikan beberapa orang siswa memiliki konsentrasi belajar yang rendah sehingga berpengaruh terhadap hasil belajar siswa tersebut.

Tugas utama guru adalah mendidik, mengajar, dan menjadikan siswa atau peserta didiknya memahami bahan pelajaran yang ia berikan sehingga dapat mencapai prestasi yang terbaik. Agar guru dapat melaksanakan tugasnya dengan baik, maka guru harus mampu menguasai berbagai kemampuan dalam mengajar. Di samping itu guru juga harus memiliki kemampuan untuk mengembangkan diri secara profesional. Seorang guru yang profesional akan memiliki kepekaan dan mampu menyelesaikan masalah yang dihadapi siswa dalam pembelajaran.

Keberhasilan siswa dalam belajar sangat ditentukan oleh strategi pembelajaran yang dilakukan oleh guru. Guru dituntut untuk memahami komponen-komponen dasar dalam melaksanakan kegiatan pembelajaran di dalam kelas. Mengajar tidak hanya sekedar mentransfer ilmu pengetahuan akan tetapi sejumlah perilaku yang akan menjadi kepemilikan siswa.

IPA merupakan salah satu mata pelajaran yang penting di Sekolah Dasar. Mata pelajaran IPA berfungsi untuk memberikan pengetahuan alam, mengembangkan keterampilan, wawasan dan keterampilan teknologi yang berkaitan dengan pemanfaatannya bagi kehidupan sehari-hari. Ciri khas dari IPA yaitu pembelajaran yang menekankan pada kepekaan siswa terhadap lingkungan alam yang ada di sekitar. Pembelajaran IPA diharapkan menjadi sarana bagi peserta didik untuk mempelajari diri sendiri dan lingkungannya.

Pembelajaran IPA di sekolah dasar pada umumnya masih banyak melaksanakan pembelajaran hanya memberikan materi kepada siswa tanpa melakukan eksperimen/ demontrasi. Seharusnya pelaksanaan pembelajaran IPA yang sesungguhnya melakukan pengalaman langsung. Pembelajaran IPA dilakukan dengan menggunakan praktek secara langsung agar siswa lebih aktif dan bersemangat dalam mengikuti pembelajaran IPA di sekolah.

Ilmu Pengetahuan Alam (IPA) merupakan salah satu mata pelajaran yang wajib dipelajari di Sekolah Dasar. Siswa akan dapat mempelajari diri sendiri dan alam sekitar dengan belajar IPA. IPA juga merupakan salah satu disiplin ilmu yang berhubungan dengan cara mencari tahu tentang alam secara sistematis, sehingga IPA bukan hanya penguasaan kumpulan pengetahuan yang berupa faktafakta, konsep-konsep, atau prinsip-prinsip saja tetapi juga merupakan suatu proses penemuan dan memiliki sifat ilmiah. Pembelajaran IPA menekankan pada pemberian pengalaman langsung dan pemahaman untuk mengembangkan kompetensi siswa agar siswa mampu menjelajahi dan memahami alam sekitar secara ilmiah. Pembelajaran IPA merupakan suatu wahana untuk mengembangkan siswa berpikir rasional dan ilmiah. Pendidikan IPA dapat membantu siswa untuk memperoleh pemahaman lebih mendalam tentang alam sekitar. Siswa wajib untuk mempelajari IImu Pengetahuan Alam terutama siswa Sekolah Dasar.

IImu Pengetahuan Alam (IPA) merupakan konsep pembelajaran alam dan mempunyai hubungan yang sangat luas terkait dengan kehidupan manusia. IPA adalah suatu mata pelajaran yang diberikan mulai sekolah dasar hingga perguruan tinggi. Adapun ruang lingkup IPA yaitu makhluk hidup, energi dan perubahannya, bumi dan alam semesta serta proses materi dan sifatnya. IPA terdiri dari tiga aspek yaitu Fisika, Biologi, dan Kimia.

IPA merupakan pengetahuan teoritis yang diperoleh atau disusun dengan cara yang khas atau khusus, yaitu dengan melakukan observasi, eksperimentasi, penyimpulan, penyusunan teori, eksperimentasi, observasi dan demikian seterusnya kait mengkait antara cara yang satu dengan cara 
yang lain (Ahmadi \& Supatmo, 2000). Dari pengertian tersebut dapat disimpulkan bahwa IPA merupakan pengetahuan dari hasil kegiatan manusia yang diperoleh dengan menggunakan langkahlangkah ilmiah atau yang sering disebut dengan metode ilmiah.

Proses pembelajaran IPA tidak sekedar teori saja, tapi lebih menekankan pada pengalaman secara langsung untuk memahami alam sekitar dan untuk mengembangkan rasa ingin tahu dan daya berpikir kritis terhadap suatu masalah. Seperti dalam Permendiknas No. 22 tahun 2006 tentang Standar Isi disebutkan bahwa IImu Pengetahuan Alam (IPA) berkaitan dengan cara mencari tahu tentang alam secara sistematis, sehingga IPA bukan hanya penguasaan kumpulan pengetahuan yang berupa fakta-fakta, konsep-konsep, atau prinsip-prinsip saja tetapi juga merupakan suatu proses penemuan. Dengan demikian pembelajaran IPA diharapkan menjadi sarana bagi siswa untuk mempelajari dirinya sendiri, lingkungan, dan alam sekitarnya untuk diterapkan dalam kehidupan sehari-hari. Sebagaimana bahwa IPA adalah usaha manusia dalam memahami alam semesta melalui pengamatan yang tepat pada sasaran, serta menggunakan prosedur, dan dijelaskan dengan penalaran sehingga mendapatkan suatu kesimpulan (Susanto, 2013).

Setelah dilakukan observasi di kelas III SD Negeri 2 Kawalu Kota Tasikmalaya ditemukan beberapa masalah dalam pembelajaran IPA, diantaranya kurangnya pemahaman siswa tentang materi yang diajarkan sehingga masih banyak siswa yang nilainya belum mencapai KKM yaitu sebesar 70. Hal tersebut ditandai dengan nilai siswa dari 25 siswa pada mata pelajaran IImu Pengetahuan Alam hanya 9 (36\%) siswa yang memenuhi standar KKM, sedangkan yang $16(64 \%)$ siswa mendapat nilai dibawah KKM.

Berdasarkan faktor-faktor yang mempengaruhi hasil belajar siswa di atas peneliti memberikan tawaran solusi yakni dengan metode Inside Outside Circle. Penerapan metode Inside Outside Circle ini diharapkan mampu memancing keaktifan siswa dalam proses belajar mengajar. Metode Inside Outside Circle adalah metode pembelajaran dengan sistem lingkaran kecil dan lingkaran besar dimana siswa saling membagi informasi pada saat yang bersamaan dengan pasangan yang berbeda dengan singkat dan teratur.

Keunggulan dari teknik pembelajaran Inside Outside Circle adalah adanya struktur yang jelas dan memungkinkan siswa untuk berbagi dengan pasangan yang berbeda dengan singkat dan teratur. Selain itu, siswa bekerja dengan sesama siswa dalam suasana gotong-royong dan mempunyai banyak kesempatan untuk mengolah informasi dan meningkatkan keterampilan berkomunikasi (Huda, 2013). Teknik Inside Outside Circle ini bisa digunakan untuk semua tingkat usia anak didik. Oleh sebab itu rumusan masalah dari penelitian ini adalah: "Apakah penerapan metode Inside Outside Circle dapat meningkatkan hasil belajar IPA pada siswa kelas III SD Negeri 2 Kawalu Kota Tasikmalaya?".

\section{METODE PENELITIAN}

Penelitian tindakan kelas ini dilaksanakan di SD Negeri 2 Kawalu Kota Tasikmalaya pada siswa kelas III SD Negeri 2 Kawalu Kota Tasikmalaya dengan jumlah siswa sebanyak 25 orang siswa. Penelitian tindakan kelas ini dilaksanakan selama dua bulan yaitu dari bulan Agustus sampai dengan September 2019 dan dilaksanakan sebanyak dua siklus dimana dalam setiap siklus dilaksanakan sebanyak dua kali pertemuan, siklus I dilaksanakan pada tanggal 19 Agustus dan 21 Agustus 2019 sedangkan siklus II dilaksanakan pada tanggal 2 September dan 4 September 2019. Dalam penelitian ini analisis data dilakukan dengan membandingkan antara skor nilai tiap siklus dengan KKM yang telah ditentukan oleh sekolah yakni sebesar 70. Oleh karena itu setiap siswa dikatakan tuntas belajarnya atau mencapai KKM jika nilai perolehan siswa $\geq 70$. Sebaliknya siswa dikatakan belum tuntas belajarnya atau belum mencapai KKM jika nilai perolehan siswa $<70$. 


\section{HASIL DAN PEMBAHASAN}

Pelaksanaan kegiatan penelitian ini dibagi menjadi beberapa tahap yakni sebagai berikut:

a. Perencanaan

Perencanaan tindakan berkaitan dengan hal-hal yang harus disiapkan untuk melaksanakan tindakan perbaikan berkaitan dengan masalah penelitian yang ditetapkan (Sumadayo, 2013). Hal -hal yang harus dipersiapkan adalah sebagai berikut:

1) Membuat rencana atau skenario pelaksanaan pembelajaran menggunakan metode Inside Outside Circle materi mengidentifikasi ciri-ciri dan kebutuhan makhluk hidup.

2) Mempersiapkan fasilitas dan sarana pendukung yang diperlukan saat proses pembelajaran berlangsung dengan menggunakan metode Inside Outside Circle materi mengidentifikasi ciriciri dan kebutuhan makhluk hidup.

3) Mempersiapkan lembar observasi guru untuk mengetahui kinerja guru dalam proses pembelajaran dengan menggunakan metode Inside Outside Circle.

4) Perencanaan tindakan pembelajaran menggunakan metode Inside Outside Circle..

5) Melakukan evaluasi terhadap pembelajaran menggunakan metode Inside Outside Circle.

6) Menyiapkan instrumen untuk menggali data hasil belajar siswa dengan menggunakan tes evaluasi.

b. Pelaksanaan

Merupakan tahapan pengaplikasian semuan perencanaan tindakan yang telah disusun (Sumadayo, 2013). Jadi, guru mengadakan proses pembelajaran menggunakan metode Inside Outside Circle. Adapun hal-hal yang dilakukan guru adalah:

1) Guru membagi fotocopy materi dan meminta siswa membaca materi tentang mengidentifikasi ciri-ciri dan kebutuhan makhluk hidup.

2) Guru meminta siswa menulis informasi tentang materi mengidentifikasi ciri-ciri dan kebutuhan makhluk hidup.

3) Guru membagi siswa menjadi dua kelompok. Kelompok pertama membentuk lingkaran kecil, mereka berdiri melingkar dan menghadap keluar. Kelompok kedua membentuk lingkaran besar, mereka berdiri melingkar dan menghadap ke dalam. Sehingga setiap siswa berpasangan dan saling berhadapan.

4) Kemudian setiap pasangan siswa dari lingkaran kecil atau lingkaran besar saling berbagi informasi yang didapat dari membaca materi tadi secara bergantian. Pertukaran informasi dimulai dari siswa yang berada di lingkaran kecil terlebih dahulu. Sehingga yang bergeser terlebih dahulu adalah siswa yang berada di lingkaran kecil. Sementara siswa yang berada di lingkaran besar diam di tempat. Dan setelah selesai barulah giliran siswa yang berada di lingkaran besar yang memberi informasi.

5) Setalah itu, siswa diminta menuliskan semua informasi yang diperoleh dan diminta membacakan di depan kelas.

c. Observasi atau Pengamatan

Pengamatan dalam penelitian tindakan kelas merupakan pengamatan yang dilakukan oleh peneliti untuk menggali data yang dilakukan dengan cara mengamati guru pada proses pembelajaran dengan menggunakan lembar observasi guru. Selain itu dilakukan tes evaluasi untuk menggali data siswa.

d. Refleksi

Refleksi merupakan kegiatan analisis, interpretasi dan eksplanasi terhadap semua informasi yang diperoleh dari observasi atas pelaksanaan tindakan. Analisis dan refleksi dilakukan untuk memaknai hasil temuan pada pelaksanaan tindakan dan menentukan tingkat keberhasilan tindakan dalam menyelesaikan masalah penelitian (Sumadayo, 2013). Pada tahap refleksi meliputi: (1) mencatat hasil observasi dan pelaksanaan pembelajaran, (2) evaluasi hasil observasi, (3) analisis hasil pembelajaran. Memperbaiki kelemahan pada siklus I, siklus II dan sebagainya. 
Pada penelitian ini, pembelajaran siklus I menggunakan metode Inside Outside Circle. Adapun tahapan dalam pembelajaran ini mencakup 4 tahapan yaitu: tahap perencanaan, tahap pelaksanaan, tahap pengamatan/observasi, dan refleksi. Pada siklus I nilai rata-rata belajar siswa meningkat menjadi 68,52 dengan ketuntasan belajar siswa sebesar $60 \%$ atau sebanyak 15 orang siswa sedangkan yang tidak tuntas sebesar $40 \%$ atau sebanyak 10 orang siswa.

Pada pembelajaran siklus II, pembelajaran masih sama yakni menggunakan metode Inside Outside Circle, namun tindakan penelitian lebih memperhatikan kendala-kendala yang terjadi di siklus I agar tidak terulang kembali pada siklus II. Pada siklus II nilai rata-rata belajar siswa terus meningkat menjadi 80,28 dengan ketuntasan belajar siswa sebesar $80 \%$ atau sebanyak 20 orang siswa sedangkan yang tidak tuntas sebesar $20 \%$ atau hanya sebanyak 5 orang siswa.

Pada siklus II penerapan metode Inside Outside Circle ini mampu meningkatkan hasil belajar siswa materi Hubungan Makanan dengan Kesehatan dibuktikan dengan data nilai setiap siklus. Metode ini juga menjadikan siswa lebih aktif dalam mengikuti pembelajaran, dan dapat menciptakann pembelajaran yang menyenangkan sehingga siswa memiliki pemahaman yang mendalam mengenai materi yang disampaikan oleh guru.

Pembelajaran IPA dengan menggunakan metode Inside Outside Circle mempunyai pengaruh terhadap hasil belajar siswa kelas III SD Negeri 2 Kawalu Kota Tasikmalaya. Hal ini dapat dilihat dari perolehan nilai siswa dari sebelum menggunakan metode Inside Outside Circle, nilai evaluasi siklus I dan evaluasi siklus II selalu mengalami peningkatan. Adapun data perbandingan nilai evaluasi antar siklus tercantum pada Tabel 1.

Tabel 1. Rekapitulasi Nilai Belajar Siswa

\begin{tabular}{|c|c|c|c|c|}
\hline No & Nama Siswa & $\begin{array}{c}\text { Pra } \\
\text { Siklus }\end{array}$ & Siklus I & Siklus II \\
\hline 1 & Siswa 1 & 50 & 75 & 90 \\
\hline 2 & Siswa 2 & 51 & 80 & 82 \\
\hline 3 & Siswa 3 & 53 & 73 & 90 \\
\hline 4 & Siswa 4 & 50 & 68 & 80 \\
\hline 5 & Siswa 5 & 55 & 72 & 75 \\
\hline 6 & Siswa 6 & 52 & 54 & 68 \\
\hline 7 & Siswa 7 & 70 & 85 & 95 \\
\hline 8 & Siswa 8 & 50 & 75 & 90 \\
\hline 9 & Siswa 9 & 51 & 72 & 80 \\
\hline 10 & Siswa 10 & 72 & 55 & 90 \\
\hline 11 & Siswa 11 & 70 & 60 & 100 \\
\hline 12 & Siswa 12 & 71 & 77 & 80 \\
\hline 13 & Siswa 13 & 50 & 73 & 70 \\
\hline 14 & Siswa 14 & 73 & 60 & 90 \\
\hline 15 & Siswa 15 & 45 & 52 & 90 \\
\hline 16 & Siswa 16 & 48 & 54 & 66 \\
\hline 17 & Siswa 17 & 71 & 75 & 80 \\
\hline 18 & Siswa 18 & 50 & 77 & 80 \\
\hline 19 & Siswa 19 & 70 & 58 & 72 \\
\hline 20 & Siswa 20 & 51 & 75 & 64 \\
\hline 21 & Siswa 21 & 72 & 82 & 90 \\
\hline 22 & Siswa 22 & 53 & 73 & 80 \\
\hline
\end{tabular}




\begin{tabular}{|c|c|c|c|c|}
\hline No & Nama Siswa & $\begin{array}{c}\text { Pra } \\
\text { Siklus }\end{array}$ & Siklus I & Siklus II \\
\hline 23 & Siswa 23 & 70 & 58 & 68 \\
\hline 24 & Siswa 24 & 55 & 70 & 75 \\
\hline \multirow[t]{5}{*}{25} & Siswa 25 & 51 & 60 & 62 \\
\hline & Jumlah & 1454 & 1713 & 2007 \\
\hline & Rata-rata & 58,16 & 68,52 & 80,28 \\
\hline & Tuntas & 36 & 60 & 80 \\
\hline & Tidak Tuntas & 64 & 40 & 20 \\
\hline
\end{tabular}

Dari data pada Tabel 1 disajikan pada Gambar 1.

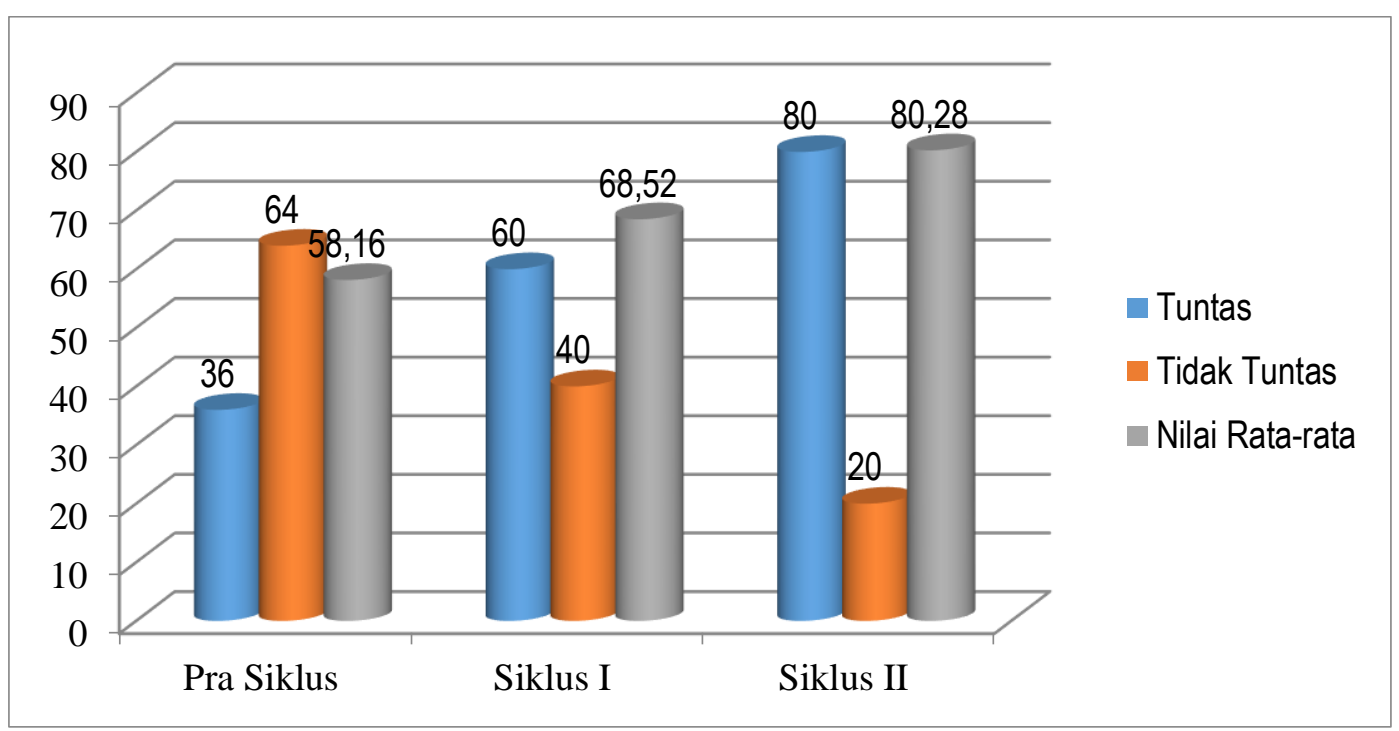

Grambar 1. Rekapitulasi Nilai Belajar Siswa

Berdasarkan hasil pelaksanaan pembelajaran dari mulai pra siklus sebelum diterapkannya metode metode Inside Outside Circle sampai dengan diterapkannya metode Inside Outside Circle dari siklus I sampai dengan siklus II, diketahui perolehan nilai rata-rata dari nilai pra siklus ke siklus I mengalami peningkatan hasil belajar siswa yakni dari 58,16 meningkat menjadi 68,52 peningkatan sebesar 10,36. Begitu juga, dengan siklus II yang mengalami peningkatan dari nilai siklus I yakni dari nilai rata-rata 68,52 menjadi 80,28 peningkatan sebesar 11,76 . Sedangkan pada ketuntasan belajar siswa pada pra siklus hanya sebesar $36 \%$ meningkat pada siklus I menjadi $60 \%$ peningkatan sebesar $24 \%$, kemudian pada siklus II meningkat kembali dibanding siklus I menjadi sebesar $80 \%$ peningkatan sebesar $20 \%$. Berdasarkan hal tersebut maka dapat diketahui bahwa pelaksanaan pembelajaran dengan mengunakan metode Inside Outside Circle ini berhasil meningkatkan hasil belajar siswa.

\section{KESIMPULAN}

Berdasarkan penelitian tindakan kelas yang dilakukan di SD Negeri 2 Kawalu Kota Tasikmalaya dapat disimpulkan bahwa metode Inside Outside Circle dapat meningkatkan hasil belajar siswa kelas III SD Negeri 2 Kawalu Kota Tasikmalaya pada mata pelajaran IPA materi mengidentifikasi ciri-ciri dan kebutuhan makhluk hidup. Peningkatan hasil belajar ditandai dengan nilai siswa yang mencapai KKM sebesar 70, yakni pada pra siklus ke siklus I mengalami peningkatan hasil belajar siswa yakni dari 58,16 meningkat menjadi 68,52 peningkatan sebesar 10,36. Begitu juga, dengan siklus II yang mengalami peningkatan dari nilai siklus I yakni dari nilai rata-rata 68,52 menjadi 80,28 peningkatan sebesar 11,76 . Sedangkan pada ketuntasan belajar siswa pada pra siklus hanya 
sebesar $36 \%$ meningkat pada siklus I menjadi $60 \%$ peningkatan sebesar $24 \%$, kemudian pada siklus II meningkat kembali dibanding siklus I menjadi sebesar $80 \%$ peningkatan sebesar $20 \%$.

1. Guru

Berdasarkan kesimpulan di atas, hal-hal yang perlu diperhatikan oleh sekolah adalah:

Dalam mengajar hendaknya guru melibatkan siswa secara aktif, sehingga siswa tidak cenderung pasif dan sebaiknya guru tidak menjadikan siswa sebagai objek penerima saja.

2. Siswa

Diharapkan siswa lebih aktif dalam mengikuti pembelajaran, dan lebih memperhatikan materi yang disampaikan oleh guru sehingga dapat meningkatkan hasil belajar, khususnya pada mata pelajaran IPA.

3. Sekolah

Bagi pihak sekolah sebaiknya mengadakan pembinaan terhadap guru untuk melatih kekreatifan guru dalam melaksanakan pembelajaran. Sehingga pembelajaran akan lebih menarik minat siswa jika gurunya lebih kreatif, dan inovatif.

\section{REKOMENDASI}

Memilih model pembelajaran yang akan dijadikan tindakan harus dilihat pula dari karakteristik materi yang akan diteliti. Hal ini bertujuan agar hasil dari penelitian dapat sesuai dengan harapan.

\section{UCAPAN TERIMAKASIH}

Ucapan terima kasih ditujukan kepada kepala SD Negeri 2 Kawalu Kota Tasikmalaya yang telah mengizinkan penelitian ini dilaksanakan dan kepada siswa kelas III SD Negeri 2 Kawalu Kota Tasikmalaya yang telah mendukung terhadap pelaksanaan kegiatan penelitian ini.

\section{DAFTAR PUSTAKA}

Ahmadi, A \& Supatmo, A. (2000). Ilmu Alamiah Dasar. Jakarta: PT Rineka Cipta.

Huda, M. (2013). Model-Model Pengajaran dan Pembelajaran. Yogyakarta: Pustaka Pelajar.

Sumadayo, S. (2013). Penelitian Tindakan Kelas . Yogyakarta: Graha Ilmu.

Susanto, A. (2013). Teori Belajar dan Pembelajaran di Sekolah Dasar. Jakarta: Kencana Prenada Media Group. 
